\title{
Mount Fuji Sign: A Rare Complication of Meningitis
}

\author{
Menenjitin Nadir Bir Komplikasyonu: Fuji Dağı Belirtisi \\ ๑ Gönül Şengöz, ๑ Filiz Pehlivanoğlu, ๑ Mustafa Ali Akçetin* \\ University of Health Sciences, Haseki Training and Research Hospital, Clinic of Infectious Diseases and Clinical Microbiology, İstanbul, Turkey \\ *University of Health Sciences, Haseki Training and Research Hospital, Clinic of Neurosurgery, istanbul, Turkey
}

\begin{abstract}
Acute bacterial meningitis is a critical condition also because of associated complications and sequelae besides being a life-threatening infection. The complications may develop due to disease itself, diagnostic procedures or treatment. Pneumocephaly is defined as the presence of air in the cranial cavity. Pneumocephalus of spinal origin may be associated with spinal trauma, penetrating injury, tumors, and infections resulting from iatrogenic causes such as lumbar puncture. Here, we present a case of a 22-year-old male with the diagnosis of acute bacterial meningitis in whom pneumocephalus occurred after lumbar puncture. In this study, we aimed to draw attention to a rare complication of lumbar puncture.
\end{abstract}

Keywords: Mount Fuji sign, lumbar puncture, meningitis, pneumocephalus
Öz

Akut bakteriyel menenjit; hayatı tehdit eden bir enfeksiyon olmasının yanı sıra komplikasyonları ve sekelleri nedeniyle de önemlidir. Komplikasyonlar; hastalığın kendine, tanı için kullanılan işlemlere ya da tedaviye bağlı olabilir. Pnömosefali, kraniyal boşluklarda hava bulunması olarak tanımlanır. Pnömosefalinin spinal nedenleri arasında; spinal travmalar, penetran yaralanmalar, tümörler, enfeksiyonlar ile lomber ponksiyon gibi iyatrojenik sebepler yer almaktadır. Bu çalışma ile menenjit tanısı ile izlenen 22 yaşındaki erkek hastada lomber ponksiyon sonrası gelişen pnömosefali sunulmuş ve lomber ponksiyonun nadir bir komplikasyonuna dikkat çekilmiştir.

Anahtar Sözcükler: Fuji dağı belirtisi, lomber ponksiyon, menenjit, pnömosefali

\section{Introduction}

Acute bacterial meningitis is a critical condition also because of associated complications and sequelae besides being a life-threatening infection. The complications may develop due to disease itself, diagnostic procedures or treatment. In this study, we aimed to draw attention to a rare complication of lumbar puncture (LP). Pneumocephaly is defined as the presence of air in the cranial cavity. Pneumocephalus of spinal origin may be associated with spinal trauma, penetrating injury, and tumors, infections resulting from iatrogenic causes such as LP (1).

\section{Case}

Family consent was obtained for publication of this case report. A 22-year-old male patient presented to our clinic due to the complaints of sudden-onset fever, headache and clouded consciousness. The examination of the patient with a history of previous meningitis two years ago revealed neck stiffness. Blood tests revealed a white blood cell (WBC) count of 20740 (93\% neutrophils) and C-reactive protein (CRP) level of $186 \mathrm{mg} / \mathrm{dL}$ (60-fold increased). Cranial computed tomography (CT) showed normal findings (Figure A). LP revealed an increased cerebrospinal fluid (CSF) pressure, blurry CSF, leukocyte count of $4800 / \mathrm{mm}^{3}$ ( $90 \%$ neutrophils), erythrocyte count of $80 / \mathrm{mm}^{3}$, protein level of $475 \mathrm{mg} / \mathrm{dL}$, and glucose level level of $53 \mathrm{mg} / \mathrm{dL}$ (simultaneous blood glucose level: 136). The patient was initiated ceftriaxone and vancomycin treatment for acute bacterial meningitis. Latex agglutination test was negative, no CSF or blood culture grew. He regained consciousness and had no fever. Neck stiffness disappeared on the $3^{\text {rd }}$ treatment day. On the $6^{\text {th }}$ treatment day, the complaint of headache started and progressively exacerbated. Neurosurgery consultation was obtained. His examination revealed clear consciousness,
Address for Correspondence/Yazışma Adresi: Gönül Şengöz

University of Health Sciences, Haseki Training and Research Hospital, Clinic of Infectious Diseases and Clinical Microbiology, İstanbul, Turkey

Phone: +90 5424169967 E-mail: gonulsengoz@gmail.com ORCID ID: orcid.org/0000-0002-1950-7288

Received/Geliş Tarihi: 12 October 2017 Accepted/Kabul Tarihi: 26 December 2017
${ }^{\circ}$ Copyright 2018 by The Medical Bulletin of University of Health Sciences Haseki Training and Research Hospital
The Medical Bulletin of Haseki published by Galenos Yayınevi.

๑Telif Hakkı 2018 Sağlık Bilimleri Üniversitesi Haseki Eğitim ve Araştırma Hastanesi Haseki Tıp Bülteni, Galenos Yayınevi tarafından basılmıştır. 

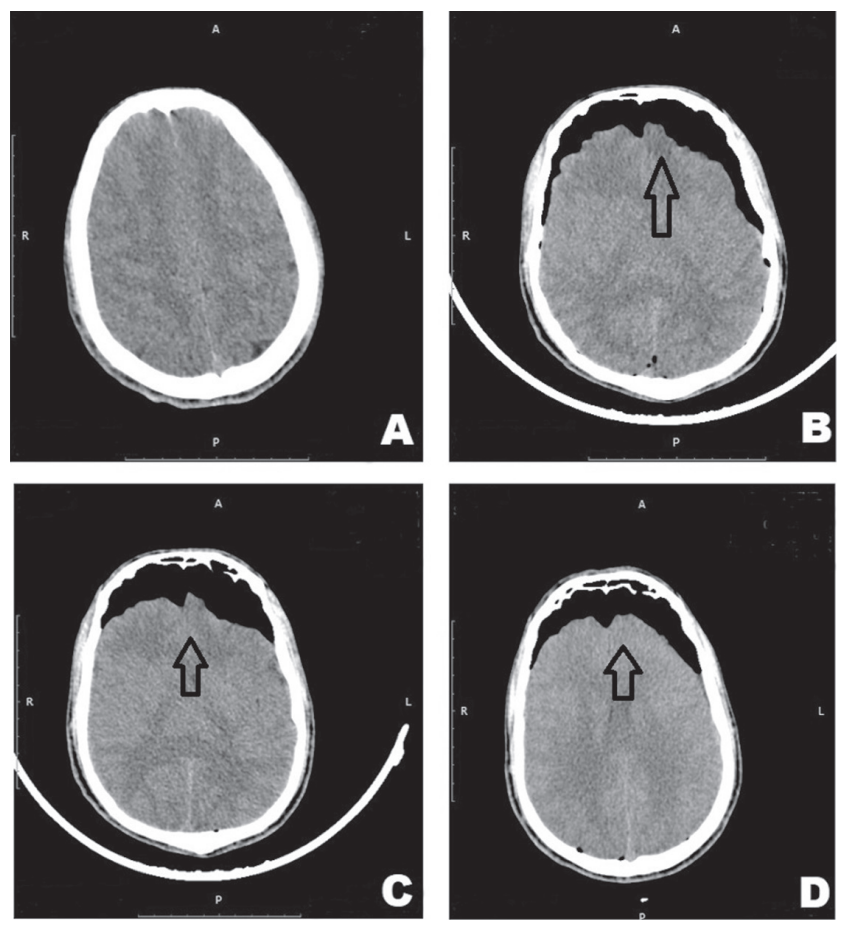

Figure. A) The first reference images. B) Treatment $6^{\text {th }}$ day, extra-axial pneumocephalus. C) Treatment $8^{\text {th }}$ day. D) Treatment $18^{\text {th }}$ day. The tips of the frontal lobes forming the characteristic silhouette of Mount Fuji

no neck stiffness or neurological deficit. His WBC was 8920 and CRP level was $13 \mathrm{mg} / \mathrm{dL}$ (4-fold increased). Cranial CT (Figure B-6 $6^{\text {th }}$ treatment day) showed a widened air space was in the bilateral cerebral hemispheres, more remarkably in the frontoparietal region, in the extra-axial CSF space (pneumocephalus) (Figure).

\section{Discussion}

Monitoring, antiepileptic medication and fluid replacement were recommended as treatment. No emergency neurosurgical intervention was considered and no other complication developed (Figure C, $8^{\text {th }}$ treatment day, Figure $D, 18^{\text {th }}$ treatment day). The patient was administered contrast agent via intrathecal route and imaging procedure was repeated. Air space levels compatible with pneumocephalus which reached $2 \mathrm{~cm}$ at the widest location were encountered at the levels of bilateral frontal lobes. Air images compatible with pneumocephalus were detected also in the subdural space at the levels of bilateral parietal convexities and cerebral falx. No osseous defect or CSF leakage was detected.

Pneumocephalus was first identified by Chiari in 1884. It has been named as Mount Fuji sign because of radiological appearance. Trauma, tumors, infections, congenital cranial abnormalities and iatrogenic factors are important in the etiology. Development of pneumocephalus following diagnostic LP has been rarely reported. Pneumocephalus after LP was associated with mechanisms, such as (1) high pressure difference between intrathecal space and the environment during LP performed in the lateral decubitus position, (2) development of pressure difference between intrathecal space and the environment caused by excessive CSF drainage and (3) development of negative pressure due to deep breathing or a sudden move during procedure (2-5).

\section{Authorship Contributions}

Surgical and Medical Practices: G.Ş., F.P., M.A.A. Concept: G.Ş. Design: G.Ş. Data Collection or Processing: G.Ş., F.P., M.A.A. Analysis or Interpretation: G.Ş. Literature Search: G.S.. Writing: G.Ş.

Conflict of Interest: No conflict of interest was declared by the authors.

Financial Disclosure: The authors declared that this study received no financial support.

\section{References}

1. Gürer B, Kertmen H, Yılmaz ER, Dolgun H, Şekerci Z. Lomber Disk Cerrahisini Takiben Ortaya Çıkan Semptomatik Pnömosefali: Olgu Sunumu. Türk Nöroşirürji Dergisi 2011;21:282-4.

2. Anandpara KM, Aswani Y, Hira P. The Mount Fuji sign. Clin Med (Lond) 2015;15:596.

3. Dabdoub CB, Salas G, Silveira Edo N, Dabdoub CF. Review of the management of pneumocephalus. Surg Neurol Int 2015;6:155.

4. Saglam M, Sivrioglu AK, Kara K, Aribal S. Mount Fuji sign following subdural haematoma evacuation. BMJ Case Rep 2013;2013:bcr2013009091.

5. Heckmann JG, Ganslandt O. Images in clinical medicine. The Mount Fuji sign. N Engl J Med 2004;350:1881. 